УДК: 355.098:2-722.53(477)

DOI: 10.33099/2707-1383-2021-40-2-18-35

\title{
Олексій Ворощук
}

ад'юнкт кафедри морально-психологічного

забезпечення діяльності військ (сил),

Національний університет оборони Украӥни

імені Івана Черняховського (Київ, Украӥна)

ORCID: https://orcid.org/0000-0002-7611-9134

Електронна nошта: oleksii_voroshchuk@ukr.net,

\section{Валентина Новікова}

старший науковий співробітник

науково-дослідного ичентру воєнної історії,

Національний університет оборони Украӥни

імені Івана Черняховського (Київ, Україна)

Електронна пошта:

valianovikova1953@gmail.com,

\section{РОЗВИТОК ВІЙСЬКОВО - РЕЛІГІЙНИХ ВІДНОСИН В УКРАЇНI (2005-2013 pp.)}

У статті висвітлено деякі історичні аспекти трансформащійних процесів у розвитку військово-релігійних відносин в Украйні у період 2005-2013 рр., а також їх роль та місие в процесі нормативно-правового врегулювання організації душпастирської опіки військовослужбовців Збройних Сил України.

На основі проаналізованих історичних фактів встановлено модель задоволення релігійних потреб військовослужбовиів Збройних Сил Украйни досліджуваного періоду у порівнянні з моделями капеланського служіння збройних сил інших держав світу.

Ключові слова: Українська церква, релігійні конфесії, духовенство, капелани, духовне виховання, душпастирська опіка, морально-психологічне забезпечення.

Поглиблення демократичних процесів, побудова відповідних духовних основ, моралізація суспільства у період 2005-2013 рр. набули біль- шої актуальності та стали одними 3 важливих маркерів розвитку сучасного суспільства, зокрема Збройних Сил України (далі - 3С України). 
Проблеми становлення та розвитку військово-релігійних відносин за часи незалежності України досліджували такі науковці та військові представники Міністерства оборони України (далі - МО України), як С. Здіорук, С. Ярмусь, В. Танчер, О. Мельник, В. Діброва, П. Костюк, В. Кротиков, Р. Коханчук, В. Яремчук, В. Мандрагеля, В. Чорний, М. Цюрупа та інші. Зокрема, характерні моделі задоволення релігійних потреб військовослужбовців в різних країнах світу було досліджено представником МО України Р. Коханчуком на початку 2000-х років (Коханчук, Р. М. 2004, с. 18-19). У працях також аналізувався процес запровадження інституту капеланства в арміях різних держав світу, у майбутній перспективі проєктувався аналогічний процес і в ЗС України.

Військово-релігійні відносини між МО України та релігійними організаціями довгий час окреслювались, переважно, участю представників релігійних конфесій у розвитку духовних процесів на рівні усталених традицій міжособистісного спілкування, подекуди втілюючись у спільні наукові та науково-практичні заходи, за результатами проведення яких засвідчувалась обопільна прихильність обох сторін щодо подальших спільних кроків та перспектив розвитку душпастирської опіки військовослужбовців.

Від початку 2005 року МО України більш активно проявляє зацікав- леність у військово-релігійних відносинах. Так, у лютому 2005 року у соборі святого Юра, що у Львові, за запрошенням Верховного архієпископа Львівського, глави Української Греко-Католицької церкви (далі - УГКЦ) Любомира кардинала Гузара, було проведено зустріч 3 представниками закладів та установ МО України та військових частин Львівського гарнізону. Під час зустрічі було проаналізовано існуючий стан військово-церковної взаємодії в Україні, зокрема у Львівському гарнізоні. Слід зазначити, що дана зустріч відбулась напередодні візиту Президента України Віктора Ющенка до Львова. У подальшому, за результатами зустрічі, глава УГКЦ Любомир кардинал Гузар довів до Президента України ініціативи щодо відновлення інституту військового капеланства у ЗС України, а також на основі зарубіжного досвіду функціонування служби військового духовенства (капеланської служби) запропонував вітчизняну модель (Діброва, В. А., Костюк, П. І., Коханчук, Р. М. \& Мельник О. І. 2010, c. 224).

У березні 2005 року президент Всеукраїнського міжконфесійного християнського військового братства С. Лисенко звернувся до МО України $з$ пропозицією співпраці у сфері створення військово-священницької служби.

На виконання доручення Президента України, директор Департа- 
менту гуманітарного, соціального розвитку та інформаційної політики МО України С. Нагорянський ініціював створення консультативно-експертної групи, до складу якої увійшли представники МО України (полковник О. Мельник), Національного інституту стратегічних досліджень (С. Здіорук, кандидат історичних наук), Національної академії оборони України (полковник запасу М. Дзюба, кандидат філософських наук; полковник запасу В. Мандрагеля, кандидат філософських наук; майор Р. Коханчук), відділення релігієзнавства Інституту філософії НАН України (В. Сленський, доктор філософських наук), Державного комітету України у справах релігії (В. Бондаренко), Всеукраїнського міжконфесійного християнського військового братства (полковник запасу С. Лисенко, кандидат філософських наук).

Наприкінці березня 2005 року за результатами роботи консультативно-експертної групи було подано заступнику МО України В. Паську аналітичну записку щодо динаміки розвитку військово-церковних взаємин, у якій зазначалося, що існуюча система нештатної душпастирської опіки військовослужбовців, насамперед, потребує подолання хаотичності у військово-церковних відносинах. Для цього пропонувалось здійснити ряд заходів: провести облік культових релігійних споруд (храмів), що містяться на території військових містечок, які перебувають на балансі
МО України; з'ясувати форми власності цих культових споруд, а також за чий рахунок відбувалась їхня розбудова (реставрація); з'ясувати прізвища священників, закріпленими за цими культовими спорудами 3 зазначенням їх конфесійної належності; з'ясувати прізвища священників (семінаристів), які за погодженням командування мають доступ до військових частин; щорічно через обласні військові комісаріати здійснювати вивчення рівня релігійності та конфесійної належності молодого поповнення, проводити опитування щодо частоти необхідності спілкування зі священником своєї конфесії; проаналізувати досвід душпастирської опіки підрозділів ЗС України, що беруть участь у міжнародних миротворчих операціях; щорічно в областях проводити моніторинг конфесійної ситуації з визначенням церков i релігійних організацій, вчення яких заперечує використання зброї своїми вірними, отримати статистику судових позовів до церков i релігійних організацій в європейських країнах за останні 2-3 роки (через відповідний запит до Міністерства закордонних справ); розробити і затвердити основи душпастирської опіки військовослужбовців 3С України; укласти домовленості про співпрацю з церквами, священники яких здійснюють душпастирську опіку військовослужбовців; розробити методичні рекомендації для командирів військових частин щодо здійс- 
нення військово-церковної взаємодії та організації душпастирської опіки віруючих військовослужбовців; розробити проєкти відповідних змін до нормативно-правових документів та пропозиції щодо зміни законодавства з питань душпастирської опіки віруючих військовослужбовців; щоквартально здійснювати аналіз звернень військовослужбовців щодо задоволення їхніх релігійних потреб, частоту використання культових релігійних споруд на територіях військових частин і конфлікти (якщо такі мали місце) в релігійній сфері (Аналітична записка. 2005).

На виконання розпорядження директора Департаменту гуманітарної політики МО України (далі - ДГП MO України), Науково-дослідний центр гуманітарних проблем 3С України розробив проєкт Положення «Про військово-душпастирську службу 3С України» (далі - Положення), в якому пропонувалося створити Департамент військового духовенства МО України. Відповідно до Положення, Головний військовий душпастир 3С України, за поданням Міністра оборони України, мав призначати глава однієї з українських церков, а чотирма його заступниками мали бути представники інших найбільших традиційних церков України. Однак, зазначене Положення не отримало загального схвалення та подальшого його втілення в життя.

Влітку 2005 року у ДГП МО України розпочалась підготовка та обго- ворення проєкту директиви Міністра оборони України «Про впорядкування питань задоволення релігійних потреб військовослужбовців ЗС України» (розробники - полковник П. Костюк, підполковник Р. Коханчук). Так, після чергового обговорення зазначеного проєкту директиви 3 представниками церков, голова Синодального управління духовно-патріотичного виховання УПЦ КП протоієрей Димитрій Садов'як, 7 грудня 2005 року, у листі-рецензії писав: «Звертають на себе увагу достатньо принципові вимоги до кандидатів з боку духовенства на співпрацю зі Збройними Силами. Приємно, що від пастиря вимагається не лише духовна обізнаність, але й патріотична продержавницька налаштованість духовної особи».

22 грудня 2005 року Міністр оборони України Анатолій Гриценко запросив представників церков і заслухав їхні пропозиції щодо удосконалення системи задоволення релігійних потреб. Міністром оборони України було запропоновано розпочати експеримент із введення штатних посад військових священників у трьох бригадах та на великому десантному кораблі «Костянтин Ольшанський», які в той час формувалися виключно військовослужбовцями військової служби за контрактом. Проте запропонований експеримент так і не було реалізовано.

21 квітня 2006 року було підписано директиву Міністра оборони 
України «Про впорядкування питань задоволення релігійних потреб військовослужбовців Збройних Сил України» № Д-25, яка була першим директивним документом, що встановлювала правовий механізм реалізації законних прав і свобод віруючих військовослужбовців. Так, документ надавав право священнослужителями здійснювати душпастирську опіку не лише 3 нагоди урочистостей. Військове командування зобов'язувалось здійснювати моніторинг кількості віруючих військовослужбовців у підлеглих військових частинах (підрозділах), наявність храмів, каплиць, молитовних кімнат і священнослужителів у місцях постійної дислокації. Заборонялося допускати у військові колективи священнослужителів, які були учасниками міжконфесійного протистояння на місцях. Відтак, документ надав легітимності тим процесам, що вже давно відбувалися, а також підштовхнув військове командування до активних дій у напрямку організації задоволення релігійних потреб віруючих військовослужбовців (Кротиков, В. П. (за заг. ред.). 2010, с. 142).

У подальшому, директива та практика іiї виконання обговорювалася на багатьох церковних нарадах, науково-практичних конференціях, семінарах та форумах.

Так, 5-7 червня 2006 року, за ініціативи МО України, спільно з Міністерством внутрішніх справ України (далі - МВС України) та Всеукра- їнським міжконфесійним релігійним християнсько-військовим братством у місті Новояворівськ Львівської області було проведено семінар-нараду на тему: «Про впорядкування питань задоволення релігійних потреб військовослужбовців». Учасники семінару-наради окреслили подальші напрями та конкретні кроки задоволення релігійних потреб військовослужбовців. Зокрема, у перспективі, було запропоновано підписання між церквами меморандуму про взаєморозуміння та спільні принципи здійснення позаштатного душпастирського служіння, а також угоди між МО України, МВС України та церквами (учасниками наради) щодо чіткого регламентування діяльності позаштатних душпастирів i використання ними стаціонарних і похідних культових споруд у межах розташування військових підрозділів. 3 метою поточного керівництва процесом здійснення душпастирської опіки, створення системи відбору, підготовки, перепідготовки, стимулювання та методичного забезпечення було запропоновано в штаті ДГП МО України та Управлінні виховної роботи Внутрішніх військ МВС України створити відповідні підрозділи (сектори роботи) $з$ питань координації діяльності щодо задоволення релігійних потреб військовослужбовців. При секторах планувалось сформувати Наглядові ради з числа ієрархів церков і керівників відповідних церковних органів, які мали забезпечува- 
ти узгодження діяльності військових душпастирів у відповідності до розробленого кодексу честі та поведінки, контроль за роботою та своєчасне відкликання осіб, які не виявляють необхідних якостей військового священника. Зазначений сектор було створено у Головному управлінні Внутрішніх військ МВС України у тому ж таки році (Діброва, В. А., Костюк, П. І., Коханчук, Р. М. \& Мельник О. I. 2010, с. 114).

Крім того, директиву МО України № 25 обговорювали під час проведення зборів священників Української православної церкви (далі — УПЦ МП) 19-20 жовтня 2006 року у м. Київ, а також під час проведення Першого з'їду головних військових капеланів УГКЦ 12-13 грудня 2007 року у м. Обухів Київської області (Діброва, В. А., Костюк, П. І., Коханчук, Р. М. \& Мельник О. I. 2010, с. 113-114).

3 метою подальшого унормування сфери задоволення релігійних потреб військовослужбовців, МО України залучало до обговорення ключових питань депутатів Верховної Ради України, представників політичних партій та громадських організацій. Так, 22 березня 2008 року МО України було ініційовано проведення круглого столу на тему: «Капеланство у Збройних Силах та інших військових формуваннях України: норма закону та практика». Співорганізаторами заходу виступили також Спілка офіцерів України, ГО «Об’єднан- ня християн-військовослужбовців України» та Всеукраїнське міжконфесійне релігійне християнсько-військове братство. Під час виступу народний депутат України В. Марущенко, акцентував увагу на необхідності створення окремих структурних підрозділів у міністерствах 3 метою просування інтересів військового капеланства.

1 квітня 2008 року заступником Міністра оборони України було підписано телеграму «Про вдосконалення питань задоволення релігійних потреб військовослужбовців 3С України» та Методичні рекомендації 3 вирішення окремих питань задоволення релігійних потреб військовослужбовців. Згідно $з$ телеграмою вимагалося з'ясувати розбіжності в облікованих і збудованих (переобладнаних, відновлених) культових релігійних споруд на території військових містечок. Рекомендації містили моделі співпраці військового командування 3 представниками церков за умови наявності у військових колективах військовослужбовців відповідних конфесій (Телеграма заступника МО України. 2008).

Зважаючи на об'єктивний стан справ та 3 метою подальшого розвитку і координації діяльності щодо задоволення релігійних потреб військовослужбовців, керівництвом МО України було створено окремий структурний підрозділ - сектор роботи 3 релігійними організаціями ДГП МО України в складі двох осіб, 
який 1 листопада 2008 року розпочав свою діяльність. Завідувачем сектору було призначено полковника запасу О. Мельника, старшим офіцером - підполковника Р. Коханчука. Першим стратегічним документом, проєкт якого було опрацьовано сектором роботи з релігійними організаціями ДГП МО України і узгоджено 3 представниками релігійних конфесій, став Меморандум про співпрацю у справах душпастирської опіки військовослужбовців $3 \mathrm{C}$ України (далі-Меморандум). Документ було підписано 10 листопада 2008 року МО України в особі заступника Мiністра оборони України В. Діброви та уповноваженими із співпраці зі ЗС України від УПЦ МП, Української православної церкви - Київський патріархат (далі - УПЦ КП), УГКЦ, Римської Католицької Церкви (далі - РКЦ), Всеукраїнського союзу об'єднань євангельських християн-баптистів (далі - ВСОСХБ), Української автокефальної православної церкви (далі - УАПЦ) та Духовного управління мусульман України (далі - ДУМ України). Меморандум передбачав поглиблення військово-релігійних відносин, а також широке використання, в межах чинного законодавства, потенціалу українських церков і релігійних організацій з метою забезпечення конституційного права особового складу на свободу совісті та віросповідання, зміцнення обороноздатності України (Меморандум про співпрацю у спра- вах душпастирської опіки військовослужбовців ЗС України. 2008).

Підписання Меморандуму вимагало унормувати у правовому полі місце військово-релігійного напряму діяльності серед завдань, що виконують ЗС України. Так, 17 квітня 2009 року було підписано наказ Міністра оборони України № 115, який затвердив Положення про Раду у справах душпастирської опіки при МО України (далі - Рада) (Положення про Раду у справах душпастирської опіки при Міністерстві оборони України. 2014).

Створення Ради було позитивно відзначено в Указі Президента України №600/2009 від 07.08.2009 р. «Про затвердження Річної національної програми на 2009 рік з підготовки України до набуття членства в Організації Північноатлантичного договору», зокрема, щодо налагодження тісної співпраці МО України 3 релігійними організаціями для задоволення релігійних потреб військовослужбовців, духовного, морально-естетичного, військово-патріотичного виховання особового складу ЗС України (Указ Президента України Про затвердження Річної національної програми на 2009 рік 3 підготовки України до набуття членства в Організації Північноатлантичного договору. 2009).

Підписання зазначеного наказу Міністра оборони України надало підстави звернутися заступнику Мiністра оборони України В. Діброві 
3 листом до Предстоятелів церков та релігійних організацій, уповноважені яких брали участь у підписанні Меморандуму, стосовно делегування своїх представників до складу Ради. Кожне релігійне об'єднання делегувало у Раду двох осіб - відповідального церкви та його заступника. Новий колегіальний орган об'єднав ієрархів, відповідальних у своïх церквах за зв'язки зі ЗС України, який мав статус представницького міжконфесійного консультативно-дорадчого органу, що діяв на громадських засадах при МО України. Відповідно до Положення, засідання Ради мали проводитись за потреби, але не менше одного разу на квартал. Раду очолював голова, який обирався іiї членами терміном на один рік. Головування в Раді - почергове. До iï складу увійшли представники релігійних організацій — підписантів Меморандуму. Водночас Рада залишалась відкритою й для представників інших конфесій та деномінацій (Рада у справах душпастирської опіки при Міноборони України прищеплюватиме військовикам патріотизм. 2009 , c. 3).

29 квітня 2009 року під час установчого засідання Ради було одностайно затверджено іiі склад, зокрема обрано Голову Ради - Архієпископа Львівського і Галицького Августина (Маркевич) (УПЦ МП) та секретаря Ради - протоісрея Любомира (Яворського) (УГКЦ). Під час установчого засідання, за ініціативи членів Ради,
3 метою засвідчення міжконфесійної злагоди і порозуміння, було змінено порядок формування керівних органів Ради й запропоновано обирати Голову та секретаря Ради від різних релігійних конфесій, а не від однієї, як пропонувалося у Положенні. Основними завданнями Ради було визначено здійснення практичних заходів щодо поетапного впровадження у ЗС України ефективної системи душпастирської опіки та створення інституту військового духовенства (капеланства) у майбутній перспективі. Протягом першого року діяльності Ради було розглянуто низку проблемних питань щодо задоволення релігійних потреб військовослужбовців під час виконання миротворчих завдань у складі миротворчих підрозділів та особливості діяльності священника в багатоконфесійному середовищі в умовах миротворчих операцій; функціонування каплиць і храмів на території військових містечок; розпочато обговорення проєкту Концепції душпастирської опіки військовослужбовців ЗС України та інші питання, які порушувалися за ініціативи членів Ради і потребували обговорення та ухвалення спільних рішень (Діброва, В. А., Костюк, П. І., Коханчук, Р. М. \& Мельник О. І. 2010, c. 124).

27 січня 2009 року у с. Зарваниця Тернопільської області відбувся II Всеукраїнський з'їзд головних військових капеланів УГКЦ спільно 3 представниками силових структур 
України, під час якого було розглянуто питання військового капеланства в УГКЦ, його сучасний стан та подальші кроки у майбутніх відносинах. Зокрема, акцентувалася увага на присутності капелана під час миротворчих місій у місцях проведення бойових дій. Від МО України на з'їзді виступили заступник директора ДГП МО України П. Костюк та представники сектору роботи з релігійними організаціями цього ж департаменту (О. Мельник та Р. Коханчук). Зокрема, представники військового відомства зазначили, що спільна діяльність Армії та Церкви значно активізувалась: збільшилась кількість священників, які працюють в армійських колективах; переобладнуються і будуються культові споруди на території військових частин; душпастирі беруть безпосередню участь у складі українських миротворчих контингентів. Також було акцентовано увагу, що у проєкті «Державної програми військово-патріотичного виховання громадян України на період до 2015 року», до відпрацювання якого долучилися представники МО України, зазначалася вимога «...забезпечити умови для задоволення релігійних потреб громадян, які служать та працюють у ЗС України через утвердження інституту військового капеланства», а відповідно до підготовлених у МО України організаційно-методичних вказівок $з$ питань реалізації гуманітарної політики держави у ЗС України у 2009 році, одним із завдань у гуманітарній сфері визначено створення сприятливих умов для підготовки введення інституту військового капеланства. Учасники з'їзду дійшли висновку, що Церква повинна докладати більше зусиль щодо інформування офіцерів ЗС України про важливість душпастирського служіння священників в українському війську. Окрім цього, делегати з'їзду висловили сподівання на поглиблення співпраці Церкви та силових структур (У Зарваниці радились капелани. 2009 , с. 8; II Всеукраїнський з'їзд головних військових капеланів Української Греко-Католицької церкви. 2009).

У січні 2009 року у рамках Всесвітнього тижня молитов за єдність християн у Свято-Покровському храмі УПЦ КП відбувся молебень за участю військовослужбовців ЗС України та інших силових структур. На заході були присутні Верховний архієпископ УГКЦ кардинал Любомир Гузар, голова відділу Патріаршої курії УГКЦ у справах душпастирства силових структур єпископ Сокальсько-Жовківський Михаїл Колтун, голова синодального управління духовно-патріотичного виховання у зв'язках зі ЗС України та іншими військовими формуваннями УПЦ КП протоієрей Димитрій Садов'як, а також православне та греко-католицьке духовенство. Слід зазначити, що захід такого масштабу проводився вдруге і представників силових 
структур взяло участь більше порівняно із попереднім роком (За єдність християн-військовслужбовців. 2009 , c. 8).

У липні 2009 року Синодальним відділом УПЦ МП по взаємодії зі Збройними Силами та іншими військовими формуваннями України було видано журнал «Віра і честь» накладом 3000 екземплярів, який був заснований у 2004 році, але за браком коштів тривалий час не випускався. Відродження випуску журналу було присвячено візиту Патріарха Російської православної церкви Кирила в Україну (Журнал «Віра і честь». 2012).

У цьому ж році у Свято-Покровському храмі при військово-медичному центрі МО України відбувся круглий стіл за участю представників церков та практично усіх силових структур держави. Під час заходу було обговорено проблемні питання, пов'язані з душпастирською опікою, зокрема випадки, коли співпраця 3 церквою, незважаючи на існування нормативно-правових актів, спрямованих на налагодження більш тісної співпраці між церквою та військом, відверто ігнорувалася деякими посадовими особами військових частин 3С України, де мали місце перешкоджання спілкуванню представників церкви 3 військовослужбовцями, у деяких випадках військове керівництво з особистих міркувань надавало перевагу представникам тієї чи іншої церкви. Присутній під час круг- лого столу представник МО України I. Колесников акцентував увагу на тому, що військове відомство намагається проводити виважену політику щодо задоволення релігійних потреб військовослужбовців, розуміючи, складність і делікатність справи, а також зазначив, що МО України наразі не визначилося у питанні впровадження інституту капеланства і продовжує вивчати досвід колишніх соціалістичних країн, у тому числі тих, які вже стали членами НАТО i в арміях яких присутні військові капелани (Співпрацюють на засадах партнерства. 2009, с. 6).

Водночас, присутність представників церков у військових колективах набуває звичного характеру. Так, у вихованні військовослужбовців Президентського полку регулярно бере участь Синодальний відділ УПЦ МП по взаємодії зі Збройними Силами та іншими військовими формуваннями, представники якого щонеділі відправляють богослужіння, проводять заняття з вивчення загальних Біблійних цінностей та сповідують військовослужбовців на території військової частини (Коли бесіда ефективніша за примус. 2009, с. 5).

Важливою подією в процесі забезпечення права військовослужбовців у задоволенні релігійних потреб стало затвердження наказу МО України від 22 квітня 2011 року № 220, яким вводилась у дію «Концепція душпастирської опіки у ЗС України» (далі — Концепція). 
В Концепції вперше сформульовано визначення низки ключових понять, які необхідні як для подальшого формування нормативно-правової бази, так і для однакового розуміння цих понять представниками всіх релігійних конфесій в Україні, а саме: військовий священнослужитель (священник, капелан, душпастир, імам); душпастирська опіка військовослужбовців; конфесія; уповноважений за душпастирську опіку військовослужбовців.

Цей документ містив у собі чітко визначену мету, завдання, функції душпастирської опіки, детально регламентовані права, обов'язки, форми діяльності військових священнослужителів, координацію їхньої діяльності 3 командуванням військових частин (підрозділів); повноваження командирів військових частин щодо задоволення релігійних потреб військовослужбовців тощо.

Щодо підготовки військових священнослужителів, згідно п. 5.1 цієї Концепції зазначається, що кожна конфесія самостійно забезпечує загальну богословську підготовку військових священнослужителів у відповідних духовних навчальних закладах - духовних академіях, університетах, теологічних факультетах, семінаріях, медресе тощо.

Основними завданнями душпастирської опіки відповідно до Концепції було визначено: навчання віруючих військовослужбовців основам віровчення; виховання любові до Бога, готовності до самопожертви заради Батьківщини і ближніх; розвиток у військовослужбовців стійких моральних якостей - справедливості, мужності, поміркованості, дисциплінованості, вірності своїм обов'язкам тощо; виховання почуття любові до Батьківщини, поваги до загальнолюдських цінностей, культурного та духовного надбання (Концепція душпастирської опіки у Збройних Силах України. 2011).

Зокрема, слід звернути увагу, що у Концепції в розділі «Очікувані результати», Міністерство визначило: «...дозволить узгодити позиції... щодо майбутнього інституту військового духовенства (капеланства)». Відтак, спостерігалася актуалізація питання щодо запровадження інституту військового капеланства у ЗС України.

Згодом, у 2013 р. Радою у справах душпастирської опіки при МО України було розроблено «Методичні рекомендації керівникам органів військового управління, командирам (начальникам) військових частин, військових навчальних закладів, установ та організацій ЗС України щодо удосконалення військово-релігійного співробітництва» (далі Методичні рекомендаціï).

Так, Методичні рекомендації в собі містили загальні положення, нормативно-правову базу у сфері забезпечення прав військовослужбовців на свободу совісті та віросповідання, інформацію щодо проведення 
аналізу релігійної обстановки, організації задоволення релігійних потреб, планування співробітництва та налагодження взаємодії з церквами (релігійними організаціями), організації проведення заходів духовного, морально-релігійного виховання військовослужбовців ЗС України, порядок створення та використання культових релігійних споруд та приміщень тощо.

За координацію з питань співробітництва 3 релігійними організаціями відповідав структурний підрозділ Департаменту соціальної та гуманітарної політики МО України (далі - ДСГП МО України). Головне управління по роботі з особовим складом ЗС України (далі - ГУРОС 3С України) здійснювало безпосередню організацію задоволення релігійних потреб військовослужбовців ЗС України.

До середньої ланки співробітництва між ЗС України та церквами (релігійними організаціями) належали структури зі сторони конфесій, які відповідали за організацію процесу задоволення релігійних потреб своїх вірних.

Також у Методичних рекомендаціях було визначено алгоритм організації співпраці з церквами (релігійними організаціями) 3 метою здійснення душпастирської опіки військовослужбовців ЗС України, які готуються до відбуття в закордонну місію в складі національного миротворчого контингенту, а також у додатку пропонувалась бліц-анкета щодо визначення релігійної ситуації (конфесійної належності) особового складу в миротворчому контингенті (Методичні рекомендації керівникам органів військового управління, командирам (начальникам) військових частин, військових навчальних закладів, установ та організацій Збройних Сил України щодо удосконалення військово-релігійного співробітництва. 2014).

5 червня 2013 року у приміщенні Центрального будинку офіцерів 3С України відбулося засідання Ради у справах душпастирської опіки при МО України. Під час засідання обговорювались пропозиції щодо проведення спільних заходів та розроблення єдиної програми навчального курсу підготовки військового священника (капелана), а також проблемні питання щодо включення військових священників до складу миротворчих контингентів 3С України для виконання міжнародних миротворчих місій, зокрема у Ліберії, ДР Конго та Косово. Також цього дня Радою було затверджено Кодекс військового священника (капелана) (далі - Кодекс). Згідно 3 положеннями Кодексу військові священники повинні поважати релігійні переконання та традиції віруючих військовослужбовців інших конфесій, як і право на свободу світогляду невіруючих. Вони також мають 3 повагою ставитись до священнослужителів інших конфесій, до їх релігійних переконань та практик (Рада 
3 душпастирської опіки при Міноборони затвердила Кодекс військового священика. 2014; Кодекс військового священика (капелана). 2014).

Таким чином, у період 20052013 рр. простежувалася стала тенденція до розвитку військово-релігійних відносин, зокрема у здійсненні практичних кроків щодо закріплення у нормативно-правовому полі нештатної моделі душпастирської опіки військовослужбовців. Якщо попередні етапи становлення військово-релігійних відносин до 2005 року характеризувалися більшою ініціативністю релігійних організацій, то в досліджуваний період простежується тенденція до більш активної діяльності з боку МО України.

На цьому етапі сформувалася трирівнева система душпастирської опіки військовослужбовців ЗС України: Рада у справах душпастирської опіки при МО України; церковно-релігійні структури, які відповідають за душпастирську опіку над військовими; місцеві священнослужителі, уповноважені церквами (релігійними організаціями) відповідати за цей напрямок співробітництва 3 військовими частинами (підрозділами).

Отже, проаналізований матеріал, дає підстави стверджувати, що у період 2005-2013 рр. відбувався розвиток військово-релігійних відносин у вигляді моделі задоволення релігійних потреб, яку вітчизняні фа- хівці охарактеризували як «світську» (етатистську), що передбачала задоволення духовних потреб представниками релігійних організацій, які не входили до структур збройних сил. Дана модель задоволення духовних потреб військовослужбовців була притаманна збройним силам пострадянських держав, на відміну від західної моделі, де в ЗС країн НАТО переважно функціонував інститут військового духовенства (капеланства) (Коханчук, Р. М. 2004, с. 14-19).

Проте, незважаючи на наявність відповідних напрацювань у вивченні досвіду функціонування інституту капеланства збройних сил інших держав світу, а також здійснення певних кроків у поглибленні військово-релігійних відносин як з боку МО України так i релігійних організацій, запровадити інститут військового духовенства (капеланської служби) у період 2005 - 2013 рр. так і не вдалося.

Відтак, МО України проводило виважену політику щодо задоволення релігійних потреб військовослужбовців, водночас перебуваючи у стані невизначеності та зволікання у питаннях здійснення конкретних кроків щодо впровадження інституту військового капеланства та продовжувало вивчати досвід колишніх соціалістичних країн, у тому числі тих, які вже стали членами НАТО і в арміях яких присутні військові капелани. 


\section{СПИСОК ВИКОРИСТАНИХ ДЖЕРЕЛ І ЛІТЕРАТУРИ}

Діброва, В. А., Костюк, П. І., Коханчук, Р. М. \& Мельник, О. I. (2010). Тріумф серия: науково-популярне видання. Київ.: Медіа Світ, 224 с.

Журнал «Віра і честь». (2012). URL: http://kapelan.org.ua/zhurnal-vira-i-chest/ [дата зверн.: 14.10.2020].

За єдність християн-військовслужбовців. (2009). Київ: Народна армія № 14 (4138), 27 січня, 8 с.

Коли бесіда ефективніша за примус. (2009). Київ: Народна армія № 35 (4159), 27 лютого, $8 \mathrm{c}$.

Кодекс військового священика (капелана). (2014). URL: https://www.mil.gov.ua/diyalnist/ zvyazki-z-gromadskistyu/rada-u-spravah-dushpastirskoi-opiki-pri-ministerstvi-oboroniukraini/normativni-dokumenti-ta-metodichni-rekomendaczii/2014/07/08/kodeks-vijskovogosvyashhenika-(kapelana)/ [дата зверн.: 20.10.2020].

Концепція душпастирської опіки у Збройних Силах України (2011 року) (наказ Міністра оборони України № 220 від 22.04.2011р.). (2011). URL: https://www.mil.gov.ua/diyalnist/ zvyazki-z-gromadskistyu/rada-u-spravah-dushpastirskoi-opiki-pri-ministerstvi-oboroni-ukraini/ normativni-dokumenti-ta-metodichni-rekomendaczii/2014/07/08/konczepcziya-dushpastirskoiopiki-u-zbrojnih-silah-ukraini/ [дата зверн.: 15.10.2020].

Коханчук, Р. (2004). Душпастирська опіка військових. Видання 2-е розширене та доповнене. Київ: Бібліотека військового душпастиря, 220 с.

Кротиков, В. П. (за заг. ред.). (2010). Душпастирська опіка у Збройних Силах Украӥни: досвід, проблеми, перспективи (Монографія). Колектив авторів. К.: НДЦ ГП ЗСУ, 258 с.

Меморандум про співпрацю у справах душпастирської опіки військовослужбовців 3С України (2008). URL: https:/www.mil.gov.ua/diyalnist/zvyazki-z-gromadskistyu/radau-spravah-dushpastirskoi-opiki-pri-ministerstvi-oboroni-ukraini/normativni-dokumenti-tametodichni-rekomendaczii/2014/07/08/memorandum-pro-spivpraczyu-u-spravah-dushpastirskoiopiki-vijskovosluzhbovcziv-zs-ukraini/ [дата зверн.: 10.10.2020].

Методичні рекомендації керівникам органів військового управління, командирам (начальникам) військових частин, військових навчальних закладів, установ та організацій Збройних Сил України щодо удосконалення військово-релігійного співробітництва. (2014). URL: https:// www.mil.gov.ua/diyalnist/zvyazki-z-gromadskistyu/rada-u-spravah-dushpastirskoi-opiki-priministerstvi-oboroni-ukraini/normativni-dokumenti-ta-metodichni-rekomendaczii/2014/07/08/ metodichni-rekomendaczii-\%282013-roku\%29/ [дата зверн.: 16.10.2020].

Нагорянський, С. Аналітична записка щодо динаміки розвитку військово-церковних взаємин (вих. 223/1/824 від 29.03.2005). (2005). Київ: ДГСРІП МОУ.

Положення про Раду у справах душпастирської опіки при Міністерстві оборони України. (2014). URL: https://www.mil.gov.ua/diyalnist/zvyazki-z-gromadskistyu/rada-uspravah-dushpastirskoi-opiki-pri-ministerstvi-oboroni-ukraini/rada-u-spravah-dushpastirskoi- 
opiki/2014/07/08/polozhennya-pro-radu-uspravah-dushpastirskoi-opiki-pri-ministerstvi-oboroniukraini/ [дата зверн.: 09.10.2020].

Рада 3 душпастирської опіки при Міноборони затвердила Кодекс військового священика. (2014). URL: http://www.ohvu.org.ua/index.php/en/news/154 [дата зверн.: 17.10.2020].

Рада у справах душпастирської опіки при Міноборони України прищеплюватиме військовикам патріотизм. (2009). Київ: Народна армія № 50 (4174), 24 березня, 8 с.

Співпрацюють на засадах партнерства. (2009). Київ: Народна армія № 7 (4131), 16 січня, $8 \mathrm{c}$.

Телеграма заступника МО України № 223/1/2-Т від 01.04.2008. (2008).

У Зарваниці радились капелани. (2009). Київ: Народна армія № 20 (4144), 04 лютого, 8 с.

Указ Президента України Про затвердження Річної національної програми на 2009 рік 3 підготовки України до набуття членства в Організації Північноатлантичного договоpy. (2009). URL: http://search.ligazakon.ua/1_doc2.nsf/link1/U600_09.html [дата зверн.: 12.10.2020].

II Всеукраїнський з’їзд головних військових капеланів Української Греко-Католицької церкви. (2009). URL: http://news.ugcc.ua/news/\%D0\%86\%D0\%86_vseukrainskiy_zizd_ golovnih_v\%D1\%96yskovih_kapelan\%D1\%96v_ukrainskoi_grekokatolitskoi_tserkvi_55687. html [дата зверн.: 14.10.2020].

\section{REFERENCES}

Dibrova, V. A., Kostiuk, P. I., Kokhanchuk, R. M. \& Melnyk, O. I. (2010). Triumf sertsia: naukovo-populiarne vydannia [Triumph of the heart: popular science edition]. K.: Media Svit, 224 s. [in Ukrainian].

Zhurnal "Vira i chest"” [Magazine "Faith and Honor"]. Retrieved from http://kapelan.org.ua/ zhurnal-vira-i-chest/ [Accessed: 14.10.2020]. [in Ukrainian].

Za yednist khrystyian-viiskovsluzhbovtsiv. (2009). [For the unity of Christian servicemen]. Narodna armiia, № 14 (4138), 8 s. [in Ukrainian].

Koly besida efektyvnisha za prymus. (2009). [When conversation is more effective than coercion]. Narodna armiia, № 35 (4159), 8 s. [in Ukrainian].

Kodeks viiskovoho sviashchenyka (kapelana). (2014). [Code of the military priest (chaplain)]. URL: https://www.mil.gov.ua/diyalnist/zvyazki-z-gromadskistyu/rada-u-spravahdushpastirskoi-opiki-pri-ministerstvi-oboroni-ukraini/normativni-dokumenti-ta-metodichnirekomendaczii/2014/07/08/kodeks-vijskovogo-svyashhenika-(kapelana)/ [Accessed: 20.10.2020]. [in Ukrainian].

Kontseptsiia dushpastyrskoii opiky u Zbroynykh Sylakh Ukrainy (2011 roku) (nakaz Ministra oborony Ukrainy № 220 vid 22.04.2011) [The concept of pastoral care in the Armed Forces of Ukraine]. URL: https://www.mil.gov.ua/diyalnist/zvyazki-z-gromadskistyu/rada-u-spravahdushpastirskoi-opiki-pri-ministerstvi-oboroni-ukraini/normativni-dokumenti-ta-metodichni- 
rekomendaczii/2014/07/08/konczepcziya-dushpastirskoi-opiki-u-zbrojnih-silah-ukraini/ [Accessed: 15.10.2020]. [in Ukrainian].

Kokhanchuk, R. (2004). Dushpastyrska opika viiskovykh. Vydannia 2 rozshyrene ta dopovnene [Pastoral care of the military / 2nd edition expanded and supplemented]. - Kyiv: biblioteka viiskovoho dushpastyria, $220 \mathrm{~s}$. [in Ukrainian].

Krotykov, V. P. (ed.). Dushpastyrska opika u Zbroinykh Sylakh Ukrainy: dosvid, problemy, perspektyvy. (2010). [Pastoral care in the Armed Forces of Ukraine: experience, problems, prospects]. (Monohrafia). Kolektyv avtoriv; Kyiv: NDTS HP ZSU, 258 s. [in Ukrainian].

Memorandum pro spivpratsiu u spravakh dushpastyrskoi opiky viiskovosluzhbovtsiv ZS Ukrainy (2008 roku). (2008). [Memorandum of Cooperation on Pastoral Care of Servicemen of the Armed Forces of Ukraine (2008)]. URL: https:/www.mil.gov.ua/diyalnist/zvyazki-z-gromadskistyu/ rada-u-spravah-dushpastirskoi-opiki-pri-ministerstvi-oboroni-ukraini/normativni-dokumenti-tametodichni-rekomendaczii/2014/07/08/memorandum-pro-spivpraczyu-u-spravah-dushpastirskoiopiki-vijskovosluzhbovcziv-zs-ukraini/ [Accessed: 10.10.2020]. [in Ukrainian].

Metodychni rekomendatsii kerivnykam orhaniv viiskovoho upravlinnia, komandyram (nachalnykam) viiskovykh chastyn, viiskovykh navchalnykh zakladiv, ustanov ta orhanizatsii Zbroinykh Syl Ukrainy shchodo udoskonalennia viiskovo-relihiinoho spivrobitnytstva [Methodical recommendations to the heads of military administration bodies, commanders (chiefs) of military units, military educational institutions, establishments and organizations of the Armed Forces of Ukraine on improving military-religious cooperation]. URL: https://www.mil.gov.ua/diyalnist/ zvyazki-z-gromadskistyu/rada-u-spravah-dushpastirskoi-opiki-pri-ministerstvi-oboroni-ukraini/ normativni-dokumenti-ta-metodichni-rekomendaczii/2014/07/08/metodichni-rekomendaczii\%282013-roku\%29/ [Accessed: 16.10.2020]. [in Ukrainian].

Nahorianskyi, A. (2005). Analitychna zapyska shchodo dynamiky rozvytku viiskovotserkovnykh vzaiemyn. (2005). [Analytical note on the dynamics of military-church relations]. (Vykh. 223/1/824 vid 29.03.2005). Kyiv: DHSRIP MOU. [in Ukrainian].

Polozhennia pro Radu u spravakh dushpastyrskoii opiky pry Ministerstvi oborony Ukrainy. (2014). [Regulations on the Council for Pastoral Care at the Ministry of Defense of Ukraine]. URL: https://www.mil.gov.ua/diyalnist/zvyazki-z-gromadskistyu/rada-u-spravah-dushpastirskoi-opikipri-ministerstvi-oboroni-ukraini/rada-u-spravah-dushpastirskoi-opiki/2014/07/08/polozhennyapro-radu-uspravah-dushpastirskoi-opiki-pri-ministerstvi-oboroni-ukraini/[Accessed: 09.10.2020]. [in Ukrainian].

Rada z dushpastyrskoii opiky pry Minoborony zatverdyla Kodeks viiskovoho sviashchenyka. (2013). [The Council for Pastoral Care at the Ministry of Defense approved the Code of the Military Priest]. URL: http://www.ohvu.org.ua/index.php/en/news/154 [Accessed: 17.10.2020]. [in Ukrainian].

Rada u spravakh dushpastyrskoi opiky pry Minoborony Ukrainy pryshchepliuvatyme viiskovykam patriotyzm. (2009). [The Council for Pastoral Care under the Ministry of Defense of Ukraine will instill patriotism in the military]. Narodna armia, № 50 (4174), 8 s. [in Ukrainian]. 
Spivpratsiuiut na zasadakh partnerstva. (2009). [Cooperate on the basis of partnership]. Narodna armiia, № 7 (4131), 8 s. [in Ukrainian].

Telehrama zastupnyka MO Ukrainy № 223/1/2-T vid 01.04.2008 [Telegram of the Deputy Minister of Defense of Ukraine] [in Ukrainian].

U Zarvanytsi radylys kapelany. (2009). [Chaplains consulted in Zarvanytsia]. Narodna armia, № 20 (4144), 8 s. [in Ukrainian].

Ukaz Prezydenta Ukrainy Pro zatverdzhennia Richnoii natsionalnoii prohramy na 2009 rik z pidhotovky Ukrainy do nabuttia chlenstva v Orhanizatsii Pivnichnoatlantychnoho dohovoru. (2009). [Decree of the President of Ukraine On approval of the Annual National Program for 2009 to prepare Ukraine for membership in the North Atlantic Treaty Organization]. URL: http://search. ligazakon.ua/1_doc2.nsf/link1/U600_09.html [Accessed: 12.10.2020]. [in Ukrainian].

II Vseukrainskyi ziizd holovnykh viiskovykh kapelaniv Ukrainskoii Hreko-Katolytskoii tserkvy. (2009). [II All-Ukrainian Congress of Chief Military Chaplains of the Ukrainian Greek Catholic Church]. URL: http://news.ugcc.ua/news/\%D0\%86\%D0\%86_vseukrainskiy_zizd_ golovnih_v\%D1\%96yskovih_kapelan\%D1\%96v_ukrainskoi_grekokatolitskoi_tserkvi_55687. html [Accessed: 14.10.2020]. [in Ukrainian].

\section{Oleksii Voroshchuk}

Adjunct,

Department of Moral and Psychological Support of Troops (Forces) Activity,

The National Defence University of Ukraine named after Ivan Cherniakhovskyi

(Kyiv, Ukraine)

ORCID: https://orcid.org/0000-0002-7611-9134

\section{Valentyna Novikova}

Senior researcher,

Research Center for Military History,

The National Defence University of Ukraine named after Ivan Cherniakhovskyi

(Kyiv, Ukraine)

\section{DEVELOPMENT OF MILITARY-RELIGIOUS RELATIONS IN UKRAINE (2005-2013)}

The theme of cooperation between the army and the church has always taken place in Ukrainian society. 
Ukraine's gaining of state independence, its transformation processes as a post-Soviet country, the presence of contradictory tendencies in its development, the elimination of communist ideology, deepened the destruction in the public consciousness and created a certain ideological vacuum in the sphere of morality and spirituality. Expanding of democracy, building the appropriate spiritual foundations, moralizing of society have become more relevant and have become one of the important markers of development of modern society, in particular the Armed Forces of Ukraine.

The article analyses the place and role of the Church in the Armed Forces of Ukraine, as well as the introduction of pastoral care in the military environment and the development of cooperation with the church. Some historical aspects of participation of religious confessions of Ukraine in the process of development of the Armed Forces of Ukraine, as well as their role and place in the spiritual and cultural education of the personnel of the Armed Forces of Ukraine are covered.

$A$ historical analysis of the state and dynamics of the development of relations between Ukrainian Orthodox churches and the state in the field of spiritual custody of servicemen is conducted. Concrete steps regarding the attempt to introduce the institute of military clergy (chaplain service) in the Armed Forces of Ukraine during 2005-2013 are considered and analysed, as well as the most objectively covered processes that became the driving force during the formation and development of military-religious relations.

On the basis of the historical facts analysed, a model of meeting the religious needs of servicemen in the period of formation and development of military-religious relations was established, as well as a system of education of servicemen in the Armed Forces of Ukraine and implementation of practical measures for organizing such work in the military environment.

Keywords: Ukrainian Church, religious denominations, clergy, chaplains, spiritual education, pastoral care. 